\title{
A Case Study on Agro-based E-Commerce Portal
}

\section{Saban Kumar K.C. ${ }^{1}$, Arun Kumar Timalsina ${ }^{2}$}

\author{
${ }^{1}$ Department of Computer and Electronics \& Communication Engineering, Kathford International College of Engg. \& Mgmt., \\ Balkumari, Lalitpur, Nepal \\ ${ }^{2}$ Department of Computer and Electronics Engineering, Institute of Engineering, Pulchowk Campus, Pulchowk Lalitpur, Nepal
}

\begin{abstract}
This paper has investigated the practice of ECommerce portal named Metrotarkari for marketing vegetables and fruit items in Kathmandu valley. A case study approach underpinned the study so as to identify current issues and practice of E-Commerce portal for vegetable and fruit items thereby adopt appropriate strategies for its sustainability in this sector. The study used explanatory form of analysis on the issues of business model, payment system, distribution system, overall challenges and marketing strategies based on the face to face interview with chief operating officer of Metrotarkari. The result shows that their $B 2 B$ feature is serving more customers than B2C feature does in daily basis. The cash on delivery has been the preferable option of payment system although they have facility of Paypal, E-Sewa and Sctmoco. The main reason behind the problem in maintaining and delivering quality items is the lack of their own inventory and their dependency on others vendors. Establishing their own cold store or inventory and appending the $\mathrm{C} 2 \mathrm{C}$ feature in their existing portal are major suggestions made to provide benefit to farmers and customers thereby sustain in this sector.
\end{abstract}

Keywords- E-Commerce, Metrotarkari.com, business model, payment gateway.

\section{INTRODUCTION}

E-Commerce is the shortened term for Electronic Commerce [1]. It is doing business transactions and communications through computer networks and networks of personal linked computers via the World Wide Web [2]. E-Commerce has established itself sophisticatedly in the developed countries; however it is yet to make roots in most of the developing countries [3].

In Nepal, The vegetable crops occupy 7.3 percent of the total cultivated agricultural land [4] which indicates the increasing value of vegetable sector in Nepalese economy. Kathmandu is a valley situated in hilly area of central Nepal. However, It has high population density and ever increasing food demand land capabilities and cultivation potential seems diminishing. The valley encloses the entire area of Bhaktapur district, $85 \%$ of Kathmandu district and $50 \%$ of Lalitpur district. Its three districts, Kathmandu, Lalitpur, and Bhaktapur, cover an area of 899 square $\mathrm{km}$ [5].

Besides, the traditional agriculture markets, there are few online markets for foods and groceries in Kathmandu valley named as MetroTarkari, Bhatbhateni, Muncha, Meroshopping, Kaymu and Foodmandu which might be some solutions in agricultural market to deliver the fresh products with reasonable prices to the digital consumers but there should be proper governing body to ensure about their reasonable product price, product quality and customer satisfaction.

\section{LITERATURE REVIEW}

In a study entitled "E-Commerce in Nepal: a case study of an underdeveloped country", Ngudup concluded that even in countries with poor infrastructure and access to information technology, evidence exists that dynamic enterprises and governments have taken advantages of the possibilities offered by E-Commerce [6]. Countries with poor communication and internet infrastructures should therefore act now in order to develop a strong E-Commerce market to prevent landing on the wrong side of the digital divide.

Similarly, In a study "Barriers to E-Commerce and competitive business models in developing countries: A case study", Kshetri indicated that economic factors (high ICT access charge, low penetration rate of credit cards), sociopolitical factor (Nepal at level 0 in adoption of digital and electronic signature (DES)) and cognitive factors (related to knowledge, skill and confidence related to E-Commerce usage) play important roles in the adaptation of business models in the context of the developing world [7]. This paper illustrated influence of Thamel.com on its business partners' ICT adoption. It provided an overview on Thamel.com's strategy to overcome some E-Commerce barriers and to overcome cognitive barriers, the company provided delivery services as well as delivery confirmation via digital pictures of gift delivery [7].

Another study entitled "A Case Study of Electronic Commerce in Nepal" recommended three projects: a business-consumer (B2C) site for marketing Buddhist Thanka paintings via the internet, a series of vertically focused workshops bringing together members of the Nepalese IT community and members in industries which may be likely E-Commerce candidates, and the establishment of a village-connectivity pilot project [8].

In the global scenario, for marketing the farm and dairy products, Walmart at US has a section named as Walmart Grocery. 'Walmart Pickup' is the new service of Walmart Grocery [9]. In pickup service, customers can simply shop their grocery lists online, choose a time to pick up their orders and 
then pull in to a designated parking area at their local stores, where associates will load the items into their cars. There are challenges to bring an entire grocery store full of products to an online market place. The vast disconnect between supplier and retailer is one of the reasons why online grocery has been so slow to take off [10].

Benefits of online shopping of agro-productsvegetable and fruit items

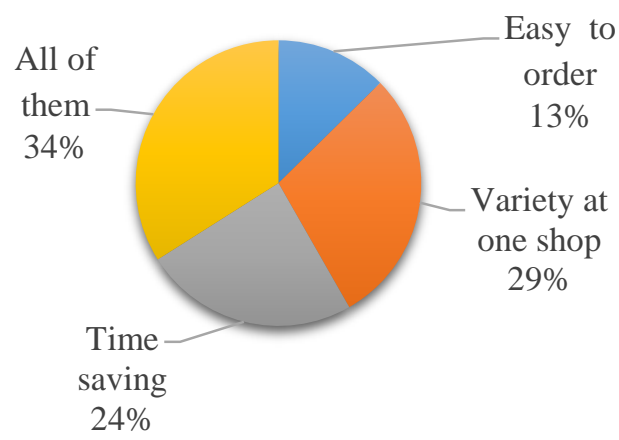

Fig.1: Benefits of online shopping of agro-productsvegetable and fruit items [11]

A study entitled "Consumer Attitudes Towards Online Grocery Shopping in Kathmandu Valley", K.C. and Timalsina mentioned that the major advantages of the online shopping of agro-products are easy to order, variety at one shop and time saving.

\section{RESEARCH METHODOLOGY}

This study used a single-case research design and primary data sources. Researcher selected an E-Commerce portal named Metrotarkari among various online portals in Kathmandu valley because it was only portal that was serving vegetables and fruit items along with other groceries to their customers in Kathmandu valley. The researcher visited its Kathmandu based office and interviewed the company's chief operating officer (COO). Subsequently, several rounds of email exchanges took place with him in Kathmandu.

Basically, a case study is an in depth study of a particular situation rather than a sweeping statistical survey. It is a method used to narrow down a very broad field of research into one easily researchable topic. A case study is based on opinion and is very much designed to provoke reasoned debate. There really is no right or wrong answer in a case study [12]. There are two different approaches to case studies; the analytical approach and problem oriented method [13]. In this study, researcher followed both approaches.

\section{RESULTS AND DISCUSSION}

The result consists of the business model of Metrotarkari, payment systems, distribution system and marketing strategies and current problems it is facing. The result is presented as follows:

A. Business Models
Regarding business models, Metrotarkari follows B2B and B2C transaction model. In B2B model, Metrotarkari is serving several restaurants, schools, canteens, INGOs, NGOs etc. every day as per the requirement. Especially in the morning time their van delivers the grocery items from vegetables to dry items to other small business units. They make offline contact with these units. Mostly phone call is used rather than internet in this transaction model. In $\mathrm{B} 2 \mathrm{C}$ model they are serving their customer directly who approach them either through website or phone call. Through this model farmers are not getting the reasonable amount where customers are charged high due to the intermediaries between them. Intermediaries between them are dealers, Kalimati vegetables and fruit center/wholesaler, sub dealers and retailers. Analyzing this distribution system it is found that farmers are not benefited by Metrotarkari, only few customers are benefitted in terms of saving time and easiness regarding shopping style. Apart from this model, another popular model is $\mathrm{C} 2 \mathrm{C}$ where a customer can directly sale their products to another customer. In case of agricultural products the real producers, the farmers, can directly approach their fresh product to the customers. The benefit of this model is that the farmers get reasonable amount of their effort where customers get fresh product. COO of Metrotarkari seems positive regarding the integration of $\mathrm{C} 2 \mathrm{C}$ features with the existing model. But there are few problems in current agricultural market of Nepal. First of all, the intervention of intermediaries is high. There are three to five levels of intermediaries before the product reaches from farmer to customer. The agro-products come from India, China and different parts of the nation to Kalimati via different intermediaries. One of the barriers regarding the implementation of this model is low literacy rate of farmers and lack of awareness regarding the use of IT and E-Commerce [14].

\section{B. Payment System}

The major headache for online business is payment system. There is no such payment gateway system to purchase the product directly from out of country. Nepal Rastra bank hasn't set up such provision yet for user to use their national account to pay directly from abroad for the goods they purchase online. Recently, Metrotarkari has used 'paypal payment gateway system' for those who want to purchase the goods from abroad to their relatives inside country. There is still a problem on it. They don't have their Paypal account institutionally but a personal account of a shareholder from abroad. Inside country they are trying to integrate the local payment gateway system such as E-Sewa, Sctmoco, I-Pay. However, there are problems regarding the integration of these systems. Metrotarakri found that these local payment systems service charges are high for them and the banking systems are not flexible as per their requirement.

Thus, the cash on delivery is only the best option for payment from customers. However, it is also not free from drawbacks. 
In other business there is provision of taking advance from customers as they are confirmed to buy the product or service. But in case of online business there is no such provision. The only basis of payment is the trust and faith between these two parties. So there is always risk on revenue generation from cash on delivery payment option. The fraud customers and mistrust of public on online business is another risk on this option.

\section{Logistic Management}

Metrotarkari has own inventory for dry grocery items but not for vegetables, fruits and dairy items. They are using another vendor's store for it. Whenever customer orders vegetable items, first of all they confirm the order with exact location. Then they decide on the vendors for shipping the ordered items. Currently Metrotarkari has three main vendors in Kalimati, Baneswor and Nakkhu who provide the ordered items to them. The distribution team of Metrotarkari consists of three staffs along with a delivery van. The job of this team is to receive the confirmed order, contact the vendors, check the quality, and package the items, location tracking and deliver the right items to the right customer at right time. They also receive the cash and the item in case of return from the customers.

\section{Marketing Strategies Based on Marketing Mix}

a) Product/Service: Metrotarkari is providing service regarding vegetables, fruit items and more than 30 new seasonal items. They are providing free home delivery service with return if customers are not satisfied. They are offering the particular items those are highly consumable during festivals and cultural events such as ghee and chakku in the first of Magh, valentine special gifts during valentines week, Kwaati during Janaipurnima and so on.

b) Place: Mainly, Metrotarkari delivers its service inside ring road of Kathmandu Valley and $3 \mathrm{~km}$ periphery of the ring road. They also serve in the main areas outside the ring road such as Bhaisepati, Hattiban, Budhanilkanta, Dhapasi and many other core areas.

c) Price: The price of the goods is similar to the current market price. It additionally provides assurance on quality and return in case of damage. Regarding gift voucher and incentives to customer Metrotarkari found reward point system that they have been providing to their customer is ineffective on their business. Thus, they are seeking other vendors to reward repeated customers.

d) Promotion: Metrotarkari is in growing stage. Promotional activities will certainly help on their business. They think that they are not ready for aggressive promotional activities yet. They advertise their portals by using social media such as facebook page called Metrotarkari. They have been participating in various social and fund raising events. Last time they participated in Idea studio program hosted by Nepal television.

\section{E. Current Problems}

The major problem that Metrotarkari is facing regarding the quality and variety of products because for vegetable items they are dependent on different vendors. If vendors do not select and package the ordered items properly then there is always a risk on items to be returned by the customer and also the bad impression to them. Ultimately, they can lose the customers' trust and chance to lose them as well. The another problem is in home delivery. Due to the traffic congestion and difficulties in finding exact location of the destination in Kathmandu there is always some delay on delivering the ordered items. Moreover, the vegetables items are very sensitive in case of their freshness. Maintaining the correct temperature during delivery which poses a threat regarding the maintenance of freshness. There is always a chance of damage or degrading on freshness and quality of such items which may lead to the customers' dissatisfaction.

\section{F. SWOT analysis of Metrotarkari a) Strengths:}

- Ordered item distribution system

- $\quad$ Free delivery strategy

- $\quad$ Product varieties-more than 30 seasonal items which is not available in local market easily

- Increasing number of customer in B2B model

b) Weaknesses:

- Inadequate research on market and customer satisfaction

- $\quad$ Lack of adequate facilities

- No precise delivery timing

- Compromise in product quality

c) Opportunities:

- Growing internet and Smartphone users

- $\quad$ increasing Publics' literacy rate and awareness is increasing

- Advertisement on Social media such as Facebook and Twitter

- $\quad$ increasing number of customers

d) Threats:

- New competitors based on online groceries such as Sastodeal, Chizbiz etc.

- Traffic congestion and difficulties in location finding

- Unmanaged urbanization

- $\quad$ Payment system complexities

The finding of the present study is different in the Latin American background where it is found closer in Indian background. As per the report by Statista, in Latin America the majority $(65 \%)$ of online shoppers preferred to pay via credit card [15] . A total of $36 \%$ of shoppers opted for digital payment systems where $35 \%$ shoppers preferred cash on delivery option [15]. On the same context, preferred payment method of online shoppers in India was to pay via cash on delivery. Cash on delivery forms an important aspect of the online shopping website in Indian online shopping market [16]. In a study based on Nepalese context, K.C. and Timalsina found that $62 \%$ People have chosen for very important option 
while shopping online groceries [11]. The present study, to some extent, supports the finding of Zwass . He found that B2B transactions are of larger volume and value, higher risks, less buyers, and different way of making purchasing decisions in comparison to $\mathrm{B} 2 \mathrm{C}$ transactions [17].

\section{CONCLUSION AND RECOMMENDATION}

The result showed that though there is lack of inventory and dependence on other vendors B2B feature of Metrotarkari.com is serving more customers than in $\mathrm{B} 2 \mathrm{C}$ feature in daily basis. The cash on delivery is the preferable option for payment although they have facility of Paypal, E-sewa and Sct-Moco. Traffic congestion and difficulties in finding exact location of the destination in Kathmandu is major reason for delayed delivery.

After analyzing the business model; payment and distribution system, the researcher has found that the current business model and distribution system seems not so beneficial for producers of agro-products. In terms of intermediation they are like other retailers. The price of Metrotarkari is similar to other retailers but Metrotarkari is providing home delivery with assurance of quality. Adaptation of another model is necessary to provide benefits to the genuine producer. Hence, the researcher suggests Metrotarkari to be both farmer and customer friendly helping the farmers sell their product in bulk amount with getting reasonable price where customers can get fresh items directly from farmer in $15-20 \%$ less price than before implying the win-win situation. For this, Metrotarkari team is suggested to establish the cold storage and a good distribution team to carry fresh items from farmers in bulk amount. In order to facilitate the professional farmers, the research suggests to integrate $\mathrm{C} 2 \mathrm{C}$ feature in their existing portal especially in local product section.

\section{ACKNOWLEDGMENT}

The authors are thankful to Mr. Karun Pant, COO of Metrotarkari.com provided the necessary information without hesitation. Special thanks to MSTIM coordinator Rajesh Kayastha, Dr. Madhusudan Kayastha, Principal, Kathford International College of Engineering and Management, Er. Krishna Gahire, Er. Bikal Adhikari, Ms. Karuna Nepal and all others for their kind support and guidance.

\section{REFERENCES}

[1] R. Kalakota and A. B. Whinston, Frontiers of electronic commerce, Singapore: Addison Wesley Longman, 199.

[2] T. Berners-Lee and M. Fischetti, Weaving the Web: The original design and ultimate destiny of the World Wide Web by its inventor, DIANE Publishing Company, 2001.

[3] U. M. Dholakia, "Concept discovery, process explanation, and theory deepening in e-marketing research: The case of online auctions," Marketing Theory, vol. 5, no. 1, pp. 117--124, 2005.
[4] MOAD, "Stastistical Information on Nepalese agriculture," Government of Nepal, Ministry of agriculture development, Singha Durbar, Kathmandu, 2012.

[5] P. R. Pant and D. Dangol, "Kathmandu valley profile," Briefing Paper, Governance and Infrastructure Development Challenges in Kathmandu Valley, 2009.

[6] P. Ngudup, "E-Commerce in Nepal: a case study of an underdeveloped country," Int. J. of Management and Enterprise Development, pp. 306 - 324, 2005.

[7] N. Kshetri, "Barriers to e-commerce and competitive business models in developing countries: A case study," Electronic Commerce Research and Applications, p. 443-452, 2007.

[8] L. Press, "A Case Study of Electronic Commerce in Nepal," International Telecommunication Union, 2000.

[9] Walmart, "About Walmart," 2015. [Online]. Available: http://grocery.walmart.com/usd-

estore/help/helppageslinkscontainer.jsp?divid=aboutWal mart. [Accessed June 2016].

[10]ZDNET, "Walmart online grocery," 2016. [Online]. Available:

http://www.zdnet.com/article/walmartonlinegrocery/. [Accessed June 2016].

[11] S. K. K.C. and A. K. Timalsina, "Consumer Attitudes Towards Online Grocery Shopping in Kathmandu Valley," in Proceedings of IOE Graduate Conference, Pulchowk, Lalitpur, 2016.

[12]M. Shuttleworth, "Case Study Research Design," 2016. [Online]. Available: https://explorable.com/case-studyresearch-design. [Accessed 2016].

[13] Monash University, "Writing a case study," Monash University, [Online]. Available: https://www.monash.edu/rlo/quick-study-guides/writinga-case-study. [Accessed 2018].

[14] S. K. K.C. and A. K. Timalsina, "Challenges for Adopting E-Commerce in Agriculture in Nepalese Context-a Case Study of Kathmandu Valley," in Proceedings of IOE Graduate Conference, Pulchowk, Lalitpur, 2016.

[15] Statista.com, "Preferred payment methods of online shoppers in Latin America as of 4th quarter 2015," 2015. [Online].

Available: https://www.statista.com/statistics/256262/preferredpayment-methods-of-online-shoppers-in-latin-america/. [Accessed 2017].

[16] A. P. Jaitapkar, "Consumer Perception Towards Online Grocery Stores," University of Mumbai , Kohinoor Business School, Kurla, Mumbai, 2012.

[17] V. Zwass, "Structure and macro-level impacts of electronic commerce," Emerging Information Technologies: Improving Decisions, Cooperation, and Infrastructure, Sage, Beverly Hills, CA, pp. 289--315, 1999. 